\title{
PERAN DAN SINERGITAS ANTAR AKTOR BADAN USAHA MILIK DESA (BUMDES) TIRTA MANDIRI, DESA PONGGOK, KABUPATEN KLATEN DALAM PERSPEKTIF GOVERNANCE
}

\author{
Nastasya Aisya Putri ${ }^{1}$, Aidinil Zetra ${ }^{2}$, dan Roni Ekha Putera ${ }^{3}$ \\ 1,2Jurusan Ilmu Politik, Fakultas Ilmu Sosial dan Ilmu PolitikUniversitas Andalas, Padang, Indonesia \\ ${ }^{3}$ Jurusan Administrasi Publik, Fakultas Ilmu Sosial dan Ilmu Politik, Universitas Andalas, Padang, Indonesia \\ Limau manis, Kecamatan Pauh, Kota Padang, Sumatera Barat \\ E-mail: nastasya.aisya.putri@gmail.com
}

\begin{abstract}
ABSTRAK. Salah satu nawacita Jokowi dan Jusuf Kalla dalam membangun Indonesia adalah membangun Indonesia dari pinggiran dengan memperkuat daerah dan desa. Tujuannya adalah memajukan perekonomian masyarakat desa dan mengatasi kesenjangan pembangunan nasional, yang dapat diwujudkan melalui Badan Usaha Milik Desa. Penelitian ini bertujuan untuk melihat bagaimana peran aktor dan sinergitas aktor dalam membentuk dan menjalankan BUMDes Tirta Mandiri. Penelitian ini menggunakan metode penelitian kualitatif dengan tipe study kasus, agar dapat memberikan pemahaman yang lebih mendalam tentang makna (arti subjek dan penafsiran) dan konteks tingkah laku serta proses yang terjadi pada faktor-faktor yang berkaitan dengan tingkah laku tersebut dan juga mengungkapkan proses kejadian secara mendetail untuk mengetahui peran aktor dan sinergitas ketiga aktor dalam menjalankan BUMDes Tirta Mandiri. Informan berasal dari aktor yang ada di BUMDes Tirta Mandiri. Untuk menguji keabsahan data yang didapatkan dilapangan dilakukan dengan teknik triangulasi sumber. Hasil dari penelitian ini menunjukkan bahwa hubungan antar aktor di BUMDes Tirta Mandiri saling berhubungan dan tidak bisa dipisahkan karena masyarakat sebagai pengguna sekaligus sebagai pengawas dan pemilik modal di BUMDes Tirta Mandiri. Selain itu, aktor-aktor dalam menjalankan BUMDes Tirta Mandiri saling bersinergi sehingga BUMDes Tirta Mandiri menjadi BUMDes yang berhasil.
\end{abstract}

Kata Kunci: Peran, Aktor, BUMDes Tirta Mandiri

ABSTRACT. One of the nawacita of Jokowi and Jusuf Kalla in developing Indonesia is to develop Indonesia from the periphery by strengthening regions and villages. The goal is to advance the economy of rural communities and address gaps in national development, which can be realized through Village-Owned Enterprises. This study aims to see how the roles of actors and the synergy of actors in forming and running BUMDes Tirta Mandiri. This study uses a qualitative research method with a case study type, in order to provide a deeper understanding of the meaning (meaning of the subject and interpretation) and the context of behavior and processes that occur in the factors related to these behaviors and also reveal the process of events detail to find out the role of actors and the synergy of the three actors in running BUMDes Tirta Mandiri. The informants came from actors in BUMDes Tirta Mandiri. To test the validity of the data obtained in the field, the source triangulation technique was used. The results of this study indicate that the relationships between actors in BUMDes Tirta Mandiri are interconnected and cannot be separated because the community is both the user and the supervisor and the owner of capital in BUMDes Tirta Mandiri. In addition, actors in running BUMDes Tirta Mandiri synergize with each other so that BUMDes Tirta Mandiri becomes a successful BUMDes.

Keywords: Role; Actor; BUMDes Tirta Mandiri

\section{PENGANTAR}

Badan Usaha Milik Desa merupakan sebuah kebijakan yang memberikan sebuah angin segar bagi masyarakat. BUMDes hadir untuk memberikan kesempatan bagi masyarakat agar dapat meningkatkan kesejahteraannya, yang dikelola langsung oleh masyarakat dan Pemerintah Desa dalam upaya memperkuat perekonomian desa dan dibentuk berdasarkan kebutuhan dan potensi desa. Badan Usaha Milik Desa memiliki tujuan yang tercantum dalam Pasal 3 Permendes No. 4 tahun 2015 yang salah satu landasan hukum dalam melaksanakan Undang-Undang Nomor 6 Tahun 2014 tentang Desa. Sesuai dengan salah satu isi Nawa Cita yaitu "membangun Indonesia dari pinggiran dengan memperkuat daerah-daerah dan desa dalam kerangka negara kesatuan“.
Membangun Indonesia dari daerah terkecil diharapkan dapat memberikan pertumbuhan ekonomi yang lebih merata serta mengakselerasikan perekonomian desa, selain itu dengan kehadiran BUMDes dapat meningkatkan potensi yang ada di desa. Kehadiran BUMDes untuk masyarakat desa dapat mengelola potensi yang ada di desa secara profesional (Zulkarnaen,2016). Selain itu, BUMDes dirancang agar masyarakat ikut berpartisipasi dalam meningkatkan perekonomian desa, karena BUMDes menjadi momentum untuk menciptakan organisasi yang tepat dan layak bagi ekonomi desa.

Eksitensi BUMDes sudah ada sejak tahun 2004 yang dicantumkan dalam undang-undang pemerintah daerah. Peraturan lebih rinci dengan pemerintah menerbitkan UU desa untuk memberikan urgensi yang layak dalam memberikan hak kepada desa mengurus rumah tangganya sendiri sebagai 
kesatuan masyarakat hukum yang tidak hanya terikat kepada pemerintah desa namun juga kepentingan masyarakat desa (Dodi, 2018). Undang-undang desa tersebut hadir agar pemerintah desa dapat meningkatkan potensi baik sumber daya alam dan sumber daya manusia yang ada di desa tersebut. Hal ini terjadi untuk meningkatkan praktek governance ditingkat lokal. Selain meningkatkan praktek governance ditingkat lokal, BUMDes hadir sebagai perbaikan ekonomi yang ada di desa.

Krisis ekonomi yang terjadi diyakini karena corporate governance yang buruk. Padahal good corporate governance dikenal sebagai solusi krisis ekonomi yang terjadi salah satunya di Indonesia dimana tidak terkelolanya perusahaan yang sesuai dengan regulasi dan banyak terjadinya praktek KKN (Korupsi, Kolusi, Nepotisme). Ketika pemerintah ingin memperbaiki ekonomi, ini berarti penerapan dengan baik prinsip good corporate governance.

Corporate governance menurut Cadbury Committee dalam Budiharta dan Gusnadi (2008), merupakan seperangkat peraturan yang mengatur hubungan antara pemegang saham, pengelola perusahaan, pihak kreditur, pemerintah, karyawan serta pemegang kepentingan intern dan ekstern lainnya yang berkaitan dengan hak-hak dan kewajiban mereka atau dengan kata lain merupakan suatu sistem yang mengatur dan mengendalikan perusahaan. Good corporate governance juga dapat dipandang sebagai sebuah mekanisme yang membantu perusahaan dalam menegakkan hukum dan peraturan yang menjelaskan hubungan antara pihak-pihak yang terkait dengan perusahan. Penting corporate governance dapat menyukseskan perusahaan dan peningkatan kesejahteraan sosial masyarakat yang tidak dapat dipungkiri.

Kehadiran good corporate governance (GCG) ditengah masyarakat bertujuan untuk mendorong system pengelolaan sebuah kegiatan usaha yang dapat mencerminkan hubungan sinergitas antar aktor dalam menciptakan kegiatan usaha yang kondusif dan menghindari budaya KKN (Korupsi, Kolusi, dan Nepotisme). Hal ini didukung oleh konsistennya aktor dalam penerapan peraturan perundangundangan. Masing-masing aktor memiliki peran dan sinergitas dalam mendukung prinsip good corporate governance.

Good corporate governance merupakan solusi bagi krisis ekonomi dalam pengelolaan perusahaan di Indonesia, hingga kini masih banyak terjadi praktek KKN (Korupsi, Kolusi, Nepotisme), ini juga terjadi pada perusahaan milik pemerintah. Kajian good corporate governance penting, karena good corporate governance merupakann solusi bagi perekonomian di Indonesia, menjadi landasan dalam mengelola perusahaan. Kajian yang dilakukan oleh
Mahpudi dan Yugni Maulana (2021) dengan judul Rent Seeking Dan Praktik Korupsi Di Tubuh Bumd: Kasus Bumd PT Banten Global Development (BGD) yang menghasilkan bahwa state actors berusaha mendapatkan hak mengalokasikan rente hasilkan dari institusi pemerintah untuk kepentingan individu dan kelompoknya. Di sisi lain, pihak perusahaan (economic actor) memperoleh keuntungan dari kebijakan yang dibuat elit politik dengan cara menyuap dan cara-cara lain yang melanggar konstitusi. Penyuapan ini menjadi bukti bahwa pemerintah hanya memikirkan keuntungan daripada kesejahteraan kelompok lain.

Hal ini juga dikaji oleh Syahran Firdaus (2017) yang berjudul Fenomena Elite Capture dalam Pengelolaan Badan Usaha Milik Desa (BUMDes): Studi kasus strategi bekerjanya kekuasaan elite dalam pengelolaan BUMDes Argosari, Desa Pulosari, Kabupaten Pemalang yang menunjukan hasil bahwa banyaknya kepentingan-kepentingan aktor di dalam suatu kebijakan yang memiliki kekuasaan dalam mengelola perusahaan, baik ditingkat nasional maupun unit terkecil yang ada di desa. Pelembagaan pada BUMDes yang tidak efektif menghasilkan kepentingan bagi beberapa kelompok yang mengakibatkan tidak efektifnya kehadiran BUMDes untuk kesejahteraan masyarakat.

Pengelolaan yang terjadi pada usaha tingkat lokal diakibatkan belum optimal peran pemerintah daerah sebagai motivator, fasilitator dan dinamisator. Dari tiga aspek tersebut, pemerintah daerah kurang optimal dalam memberikan dukungan sarana dan prasarana serta perijinan kawasan, baru optimal dalam memberikan dukungan pengembangan kapasitas. Kajian ini dilakukan oleh Ibrahim,dkk (2020) yang berjudul Dari Ekonomi Ke Ekonomi Politik: Transformasi Setengah Hati Sektor Ekowisata Di Bangka Belitung. Kajian ini menghasilkan bawah tidak dapat dipungkiri bahwa pemerintah local menjadi aktor penting dalam mengelola aset yang ada di daerah. Peran pemerintah daerah menjadi pusat dalam pengelolaan usaha yang ada di daerah. Pemerintah daerah belum mengoptimalkan perannya sehingga tidak dapat dipungkiri bahwa pengelolaan masih belum maksimal.

Kajian berikutnya oleh Sandy (2018) yang berjudul Dimensi Ekonomi Politik Dalam Konflik Tata Kelola Pertambangan (Studi Kasus Surat Keputusan Gubernur Bangka Belitung Tentang Penghentian Sementara Operasional Pertambangan Laut PT Timah, Tbk Tahun 2016) yang menghasilkan bahwa selain itu, peran pemerintah sering terjadi tumpang tindih terhadap aturan hukum dan implementasi regulasi yang berbenturan antar aktor pemilik kuasa yang memiliki akses kontrol dalam mengelola kebijakan di perusahaan, maupun 
economic actor yaitu pihak perusahaan. Konsistensi dan kekuataan hukum dan politik harus dipertegas dan lebih kokoh dalam konteks relasi kuasa agar mewujudkan ekonomi yang selaras, adil, dan berkelanjutan serta bukan hanya kepentingan dari pihak pembinis saja.

Termasuk juga perusahaan desa yang disebut dengan BUMDes yang memiliki landasan hukum yang diatur dalam Undang-Undang dan Peraturan Daerah. Kajian ini dilakukan oleh Harjanti,dkk (2019) yang berjudul Menakar tata kelola Badan Usaha Milik Desa di Indonesia. Dilihat dari sebagian besar BUMDes di Indonesia memiliki AD/ART yang jelas, tetapi dalam pengelolaan dan akuntabilitas keuangan belum dapat dilaksanakan dengan baik. Ini terjadi karena rendahnya penerapan good corporate governance pada aspek sustainabily dan akuntabilitas, selain itu usia BUMDes relatif masih muda dan perlu diperhatikan keterlibatan aktor dalam kondisi dan keadaan desa agar kehadiran BUMDes memberikan efek positif dalam perekonomian desa. Kondisi dan keadaan desa menjadi factor penting dalam mengelola BUMDes yang dilakukan oleh aktor-aktor yang ada di desa. Ini tidak terlepas bagaimana aktor-aktor tersebut dapat bersinergi, baik pemerintah desa, maupun masyarakat serta pihak lainnya dalam menerapkan good corporate governance di BUMDes.

Dalam kajian ini, prinsip good corporate governance di BUMDes dapat diterapkan karena BUMDes merupakan unit usaha yang ada di tingkat desa wujud dari pengelolahan ekonomi produktif desa. pengelolaan ini harus secara mandiri dan professional serta tidak lepas dari sinergitas aktoraktor yang ada di desa, sehingga BUMDes dapat menjadi penguat ekonomi desa. Unit pergerakan ekonomi terkecil yaitu BUMDes Tirta Mandiri di Desa Ponggok. Desa Ponggok yang memiliki efek positif atas kehadiran BUMDes Tirta Mandiri dengan kehadiran BUMDes Tirta Mandiri memberikan pergerakan ekonomiyang tinggiuntuk perkembangan masyarakat dan desa itu sendiri. Terbukti dengan bagaimana perubahan perekonomian masyarakat tersebut. Ini tidak terlepas dengan perlembangaan usaha (pelembagaan BUMDes) untuk memperkuat objek masyarakatnya yang tujuan utamanya untuk kedaulatan rakyat Desa Ponggok. Karena pendapatan BUMDes menjadi PAD dan diberikan kepada warga desa dalam program pembangunan untuk mencapai kesejahteraan warga desa. Berdasarkan dengan nilainilai dan prinsip good corporate governance dalam menjalankan BUMDes Tirta Mandiri.

Dari penjelasan tersebut dapat dilihat perbedaan denganpenelitiansebelumnya, penelitiansebelumnya memiliki fokus kepada peranan aktor pemerintah dan swasta yang lebih memiliki kekuasaan dalam menjalankan perusahaan, bahkan kebijakan yang telah ditetapkan tidak dijalankan sesuai hukum yang ada. Konflik yang terjadi memberikan efek kepada perekonomian dan masyarakat. Sedangkan kajian ini membahas bagaimana kebijakan yang telah dibuat dijalankan sesuai dengan kebutuhan tanpa melanggar hukum dengan melibatkan semua element aktor dalam menjalankan system perekonomian ditingkat desa yaitu BUMDes Tirta Mandiri di Desa Ponggok.

Desa Ponggok salah satu desa yang mendirikan BUMDes yang terletak di Kabupaten Klaten, merupakan salah satu desa yang berasal dari kawasan Desa Mataram Kuno yang di dalamnya menyimpan air yang melimpah. Desa Ponggok dulunya masuk daftar desa termiskin se-Provinsi Jawa Tengah karena tingginya angka pengangguran dan rendahnya angka pendidikan. Untuk memanfaatkan potensi yang dimiliki Desa Ponggok, pada tanggal 15 Desember 2009 BUMDes Tirta Mandiri resmi didirikan di Desa Ponggok dengan landasan Peraturan Pemerintah Kabupaten Klaten Nomor 2 Tahun 2009 tentang Badan Usaha Milik Desa.

BUMDes Tirta Mandiri hadir bukan hanya memiliki usaha, namun BUMDes Tirta Mandiri juga memilki program-program untuk masyarakat Desa Ponggok ini bertujuan untuk meningkatkan kesejahteraan masyarakat melalui pengelolaan potensi Sumber Daya Alam (SDA) dan Sumber Daya Manusia (SDM) secara maksimal. Walaupun BUMDes Tirta Mandiri pada saat ini sudah dapat dikatakan sukses dalam memanfaatkan sumber daya yang telah ada, namun periode awal BUMDes Tirta Mandiri tidak memiliki perjalanan yang mudah, walaupun sudah menjadi keputusan bersama tetapi masih ada kelompok masyarakat yang memandang sebelah mata.

Ketika perumusan kebijakan pembentukan BUMDes Tirta Mandiri seharusnya melibatkan ketiga aktor dalam perspektif governance yaitu pemerintah desa sebagai state, BPD dan masyarakat desa sebagai society, dan dunia usaha, aktor tersebut bukan hanya terlibat dalam pembentukan namun sinergitas antar aktor dalam menjalankan BUMDes Tirta Mandiri merupakan indikator keberhasilan perspektif good corporate governance. Keberhasilan BUMDes Tirta Mandiri ini tidak terlepas dari peran aktor pemerintah sebagai pembuat kebijakan berdirinya BUMDes Tirta Mandiri, dunia usaha yang memiliki peran dalam mengelola BUMDes Tirta Mandiri serta aktor masyarakat sebagai pengguna produk dan jasa serta keterlibatan perwakilan masyarakat yang disebut juga sebagai BPD sebagai penyelenggara musyawarah desa.

Studi ini penting karena keberhasilan BUMDes Tirta Mandiri dalam meningkatkan pendapatan desa, dan kehadiran BUMDes di Desa Ponggok 
menjadikan Desa Ponggok menjadi desa percontohan dalam pengelolaan BUMDes, dengan kehadiran BUMDes selain memanfaatkan potensi yang ada di desa juga menciptakan lapangan pekerjaan dan menghasilkan omset yang melebihi dana desa yang diberikan pemerintah pusat kepada desa. Kehadiran BUMDes menjadikan Desa Ponggok yang dulu merupakan desa tertinggal hingga desa mandiri. Hal ini tidak terlepas dari aktor-aktor good corporate governance dalam perumusan suatu kebijakan publik dan mengaplikasikan kebijakan tersebut. Selain itu, dapat dilihat apakah dalam perumusan dan mengaplikasikan kebijakan apakah ada aktor lain selain aktor governance atau terjadinya bias aktor dalam mengaplikasikan kebijakan.

Masalah dalam penelitian ini terdiri dari dua pertanyaan yaitu peran aktor dalam pembentukan dan sinergitas antar aktor dalam menjalankan BUMDes Tirta Mandiri dalam perspektif governance. Penelitian ini bertujuan untuk menjelaskan peran aktor dalam pembentukan BUMDes Tirta Mandiri dan menjelaskan bagaimana sinergitas aktor-aktor tersebut dalam menjalankan BUMDes Tirta Mandiri.

\section{METODE}

Penelitian ini tentang kebijakan pada tingkat desa dalam memajukan dan mensejahterakan masyarakat desa. Kebijakan ini hadir dari salah satu nawacita Jokowi yaitu kemandirian Desa. Kebijakan ini adalah BUMDes Tirta Mandiri di Desa Ponggok. Penelitian ini berfokus kepada bagaimana peran masing-masing aktor di Desa Ponggok dalam merumuskan pembentukan BUMDes Tirta Mandiri dan bagaimana aktor tersebut bersinergitas dalam menjalankan BUMDes Tirta Mandiri.

Penelitian ini menggunakan metode pendekatan kualitatif dengan tipe study kasus dengan type instrumental agar dapat memberikan pemahaman yang lebih mendalam dan menegaskan tentang peran dan sinergitas aktor dalam BUMDes Tirta Mandiri. Studi kasus instrumental digunakan oleh peneliti pada penelitian ini agar dapat memperoleh informasi dengan jelas dan menggambarkan secara tertulis tentang fenomena yang peneliti angkat untuk disusun ke dalam laporan penelitian yang kompleks dan efisien, sehingga apa yang menjadi tujuan dari penelitian ini dapat menjawab dengan baik.

Penelitian ini dilakukan di Desa Ponggok dengan informan kunci yang dipilih melalui teknik snowball sampling agar informan kunci dapat digunakan sebagai dasar dan panduan untuk memberikan informasi lebih lanjut. Informan kunci dipilih berdasarkan kedalaman pengetahuan tentang informan yang diperlukan dan memberikan informasi dan rujukan kepada informan lain. Pengumpulan informasi ketika sampai pada tahap titik jenuh dapat diartikan bahwa informasi yang diperoleh berulang dan tidak lagi baru, maka proses wawancara dianggap lengkap dan selesai. (Salganik, 2007)

Dalam penelitian ilmu-ilmu sosial data memegang peranan penting untuk mendukung menjabarkan analisis dalam pembahasan tentang permasalahan yang akan diuraikan. Analisis data pada penelitian ini adalah peneliti hanya menggunakan teknik pengumpulan data dan pengumpulan dokumen serta menggunakan informan triangulasi sumber data.

\section{HASIL DAN PEMBAHASAN}

\section{A. Peran Aktor BUMDes Tirta Mandiri dalam Perspektif Governance}

Kemunculan good corporate governance di Indonesia karena krisis ekonomi yang terjadi. Permasalahan terjadi karena perusahan tidak sesuai dengan regulasi dan kesepakatan yang telah ditentukan. Tata kelola dalam social enterprise mengutamakan terlibatnya semua aktor yang ada. Seiring meningkatnya angka partisipasi masyarakat dan dianggap lebih partisipatif namun menurut Furniss (1974), konsekuensi dari adanya arus desentralisasi akan selalu melibatkan banyak proses dan institusi baru yang dihadirkan sebagai wujud penyegaran struktur institusi lama. Arus desentralisasi sebagai upaya mencapai kemandirian tidak serta merta menggusur elite-elite predatoris desa yang sudah terlanjur menjadi elit penentu kebijakan. Kehadiran lembaga baru seperti BUMDes di desa seperti menyediakan arena besar bagi aktor politik baru maupun lama untuk kemudian berkontestasi menancapkan pengaruhnya.(Himawan, 2001)

Pada Konsep Good Corporate Governance, terdapat tiga pengelompokan pada aktor yaitu: 1) Negara dan perangkatnya membuat peraturan perundang-undangan yang menunjang usaha yang sehat, efisien dan transparan, melaksanakan peraturan perundang-undangan dan penegakan hukum secara konsisten (consistent law enforcement). 2) Dunia usaha sebagai pelaku pasar menerapkan GCG sebagai pedoman dasar pelaksanaan usaha. 3) Masyarakat sebagai pengguna produk dan jasa dunia usaha serta pihak yang terkena dampak dari keberadaan perusahaan, menunjukkan kepedulian dan melakukan kontrol sosial (social control) secara obyektif dan bertanggung jawab.

\section{a. Peran Negara}

Negara merupakan aktor yang paling domain karena memegang peranan penting dalam mewujudkan good corporate governance. (Serdamayanti, 2004) Hal ini dikarenakan domain state berfungsi dalam pengaturan yang memfasilitasi domain sektor 
dunia usaha swasta dan masyarakat (society), serta fungsi administrasi. Pemerintah Desa Ponggok merupakan wujud local state yang ada di Desa Ponggok yang merupakan kunci dalam membentuk sebuah kebijakan.

Besarnya peranan pemerintah dalam menjalankan pemerintahan serta memiliki tujuan dalam mensejahterakan masyarakat yang menjadi point penting dalam melakukan tugasnya. Salah satunya mendirikan BUMDes Tirta Mandiri dimana dalam pemilihan struktur harus sesuai dengan kebutuhan dan kapasitas demi kepentingan bersama.

Badan usaha milik desa dibentuk/didirikan oleh pemerintah desa yang kepemilikan modal dan pengelolaannya dilakukan oleh pemerintah desa dan masyarakat desa. Pemerintah desa memiliki peranan yang sangat penting dalam mendirikan BUMDes Tirta Mandiri. Koordinasi yang dilakukan kepala desa kepada staff yang ada di struktur perangkat desa serta tidak lupa kepada perwakilan masyarakat yang disebut juga dengan Badan Permusyawaratan Desa.

Ketika ingin mendirikan BUMDes Tirta Mandiri, kepala desa meminta bantuan melalui rektor UGM untuk mengirimkan mahasiwa KKN di Desa Ponggok. Hal ini bertujuan agar pemerintah desa mengetahui bagaimana permasalahan-permasalahan yang ada di desa karena tujuan mendirikan BUMDes agar dapat memajukan dan mensejahterakan ekonomi desa. Hal ini disampaikan oleh Kepala Seksi Kesejahteraan dan Pelayanan Pemerintah Desa Ponggok dalam kutipan wawancara berikut ini:

"Koordinasi yang kami lakukan dengan arahan kepala desa. Ponggok merupakan kategori desa miskin. Tahun 2008 kepala desa memberikan surat kepada UGM untuk meminta anak-anak UGM KKN selama 3 tahun berturut-turut KKN di Desa Ponggok. Ternyata yang membuat kami miskin adalah terlalu banyak rentenir di tengah masyarakat, masyarakat Desa Ponggok meminjam duit kepada rentenir. Sehingga kami putuskan untuk membuat lembaga baru, dengan mengumpulkan seluruh perangkat desa dan BPD melalui musyawarah desa."

BUMDes Tirta Mandiri merupakan salah satu strategi agar perekonomian desa membaik yang terdapat dalam RPJM Des 2007, hal ini juga disampaikan oleh Ketua DPD dalam kutipan wawancara berikut:

"Di RPJM desa pada tahun 2007 sudah membuat dan memikirkan strategi bagaimana Desa Ponggok bisa menjadi desa yang baik, BUMDes adalah strategi bagaimana dapat menaikkan ekonomi desa dan memanfaatkan sumber daya yang ada di desa".
Setelah pembentukan BUMDes Tirta Mandiri pemerintah desa memiliki peran dalam BUMDes Tirta Mandiri sebagai penasehat dan dewan komisaris. Hal ini terjadi agar pemerintah desa dapat mengetahui bagaimana jalannya BUMDes Tirta Mandiri. Terjadinya perubahan pada tahun 2018 pada AD/ART BUMDes Tirta Mandiri bahwa organisasi pengelolalaan BUMDes terpisah dari organisasi pemerintah desa, sehingga pemerintah desa secara keseluruhan tidak ikut terlibat dalam struktur BUMDes Tirta Mandiri.

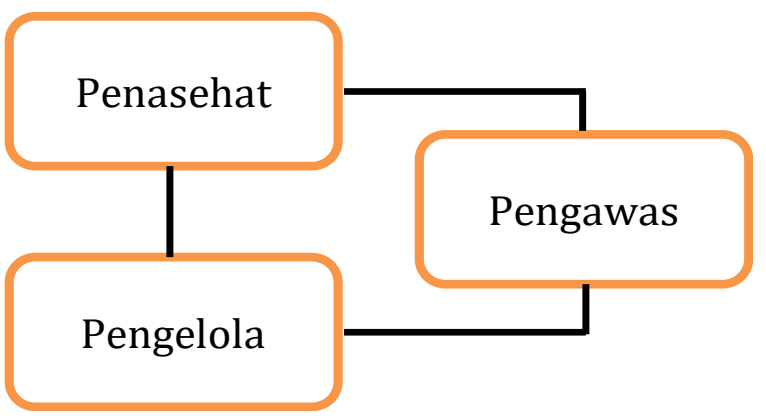

Sumber: Data Sekunder yang diolah oleh peneliti dari AD/ART BUMDes Tirta Mandiri 2018 tahun 2020

\section{Gambar 1. Struktur BUMDes Tirta Mandiri tahun 2018}

Peran pemerintah desa lebih didominasi oleh Kepala Desa Ponggok yang artinya bahwa Kepala Desa Ponggok merupakan struktur dari pemerintah desa. Bukan hanya sebagai penasehat, kepala desa juga memberikan persetujuan pada laporan pertanggung jawaban pengelola BUMDes dan mempertanggung jawabkan kepada masyarakat di musyawarah desa yang dilakukan setiap satu kali dalam setahun.

Dalam mewujudkan good corporate governance ada tiga pilar yang sangat berkaitan dan merupakan hal penting yaitu transparansi, partisipasi dan akuntabilitas serta satu elemen penting yaitu value for money (ekonomi, efisiensi dan efektifitas). (Mardiasmo, 2009) Pada Pemerintah Desa Ponggok, bahwa kepala desa memberikan laporan pertanggungjawaban di musyawarah desa yang diselenggarakan oleh Badan Permusyawaratan Desa yang dilakukan pada akhir bulan Maret setiap tahunnya, hal ini memberikan bukti bahwa masyarakat dapat melihat transparansi yang ada di BUMDes Tirta Mandiri.

Walaupun pada awal pembentukan BUMDes Tirta Mandiri, pemerintah desa memiliki kesulitan karena peraturan yang ada untuk landasan berdiri BUMDes Tirta Mandiri, serta konflik yang terjadi di dalam internal pemerintah desa, namun mereka dapat mengatasi untuk tetap menjalankan BUMDes Tirta Mandiri agar dapat memberikan efek yang positif bagi Desa Ponggok. Peranan yang sangat penting yang dilakukan pemerintah desa dalam BUMDes Tirta Mandiri, baik pada dasar peraturan BUMDes 
Tirta Mandiri dan transparansi yang dilakukan kepala desa yang mempertanggung jawabkan BUMDes Tirta Mandiri kepada Badan Permusyawaratan Desa di musyawarah desa juga memberika aset desa sebagai bentuk awal berdirinya BUMDes Tirta Mandiri.

Pemerintah desa hingga kini selalu melakukan baik ketika pemilihan struktur dan kebijakan yang akan dijalankan BUMDes Tirta Mandiri dengan cara musyawarah bersama masyarakat dan kepentingan yang hadir adalah kepetingan bersama. Pemerintah desa ketika menjalankan BUMDes menyerahkan sepenuhnya kepada pengelola, ini bertujuan agar tidak terjadi konflik dan kepentingan dari pihak pemerintah desa dalam tubuh pengelola BUMDes Tirta Mandiri.

\section{b. Peranan Dunia Usaha}

Pihak ketiga merupakan perusahaan swasta/ pihak ketiga yang aktif dalam mekanisme sistem pasar, seperti industri pengolahan perdagangan, perbankan, dan koperasi termasuk kegiatan sektor informal bahkan ada pihak swasta yang memiliki peran. (Sedarmayanti,2014). pihak ketiga juga memberikan dana dalam bentuk investasi dan pemodalan dalam suatu instansi atau lembaga.

BUMDes Tirta Mandiri merupakan lembaga yang ada di Desa Ponggok yang secara struktur dan administrasi terpisah dari pemerintah desa. Dana awal pada pembentuk BUMDes Tirta Mandiri berasal dari pihak ketiga (investor) yang ikut terlibat dalam permodalan yang ada di BUMDes Tirta Mandiri. Dana awal pada pembentuk BUMDes Tirta Mandiri dikutip dari wawancara yang dilakukan peneliti kepada Direktur BUMDes Tirta Mandiri ke-3 sebagai berikut :

"Jumlah KK 560, pemerintah desa hanya dapat memberikan sebuah mandat agar dapat mengelola aset desa. BUMDes agar dapat berdiri dibutuhkan sebuah dana operasional sehingga dibutuhkan dana per KK yaitu per KK 5jt. Awalnya hanya $15 K K$ dana inilah yang diputarkan untuk mengembangkan dan mengelola BUMDes"

Investor atau pihakketiga yang dimaksud adalah warga atau organisasi yang ada di Desa Ponggok. Hal ini merupakan bentuk usaha pemerintah desa dalam memberikan dampak kehadiran BUMDes bagi masyarakat dari investasi tersebut. Selain itu, agar hasil dari BUMDes Tirta Mandiri hanya berada di Desa Ponggok.

Selain investor yang merupakan masyarakat, BUMDes Tirta Mandiri juga bekerja sama dengan pihak perbankan. BNI ikut serta dalam menjalankan BUMDes Tirta Mandiri dengan memberi layanan agent 46 serta pelatihan-pelatihan yang diberikan
BNI kepada staff BUMDes Tirta Mandiri. Hal ini disampaikan oleh Direktur BUMDes Tirta Mandiri ke-3 dalam kutipan wawancara berikut ini :

"Adaa, adanya BNI. Hal yang membuat kendala di desa adalah SDM atau hanya seadanya. Kami membutuhkan pihak ketiga yaitu BNI. Mendapingi keuangan dan pendapatan kami lalu feedbacknya BNI memberikan pelatihan seperti cash manajemen, service dalam meningkatkan SDM selain itu ada dibidang keuangan."

Pihak BNI selaku pihak ketiga memiliki peran yang sangat besar dalam perjalanan BUMDes Tirta Mandiri. Dilihat dari bentuk kerjasama yaitu Agent 46 serta pelatihan-pelatihan yang diberikan BNI kepada staff BUMDes Tirta Mandiri. Pelayananpelayanan yang diberikan oleh BNI kepada BUMDes Tirta Mandiri membuat BUMDes Tirta Mandiri lebih unggul dari BUMDes lainnya.

Peran pihak ketiga lebih difokuskan pada memberikan pelatihan. Selain BNI juga ada pelatihan keuangan dari pihak akademik yaitu STAN kepada pengelola keuangan BUMDes Tirta Mandiri. hal ini bertujuan agar BUMDes Tirta Mandiri dapat mengikuti perkembangan teknologi dalam bidang keuangan.

Peranan pihak dunia usaha dalam BUMDes Tirta Mandiri memiliki peranan baik dalam permodalan dan bentuk kerja sama lainnya. Pada perspektif ilmu politik, setiap aktor memiliki peran yang sangat menentukan dalam merumuskan, melaksanakan dan mempertimbangkan setiap konsekuensi kebijakan yang dibuat. Peranan pihak ketiga dalam melaksanakan kebijakan yang dibentuk dalam sistem kerja sama agar tidak ada pihak yang akan dirugikan dalam kata lain kedua pihak mengetahui dan menerima konsekuensi dari kebijakan tersebut. (Suharko,2005) hubungan yang terjalin dapat dilihat bagaimana pihak dalam mengembangkan BUMDes Tirta Mandiri.

\section{c. Peranan Masyarakat}

Kelompok masyarakat pada konteks governance menghendaki masyarakat untuk berpartisipasi dalam mengelola pemerintahan. Partisipasi yang dilakukan masyarakat dapat kita lihat pada munculnya lembaga badan permusyawaratan desa yang terdiri dari perwakilan masyarakat. Munculnya forum masyarakat yang disebut musyawarah desa yang menjadi penyalur anspirasi masyarakat ke pemerintah desa dan BPD. Diketahui bahwa good governance dapat dikatakan pemerintahan yang menghormati kedaulatan rakyat.

Aktor masyarakat (society) memiliki peran ketika pembentukan BUMDes Tirta Mandiri. Ketika pembentukan BUMDes Tirta Mandiri masyarakat 
diwakili oleh BPD membuat forum musyawarah desa yang bertujuan agar pemerintah desa dapat menyampaikan rencana dalam membentuk BUMDes Tirta Mandiri. BPD sebagai aktor yang berperan dalam mewakili masyarakat sebagai pengawas terhadap pemerintah desa. Partisipasi menurut United Nations Development Programme (UNDP) bahwa setiap warga negara mempunyai suara dalam pembuatan keputusan, baik secara langsung maupun melalui intermediasi institusi legitimasi yang mewakili kepentingannya. Hal ini disampaikan oleh Ketua Badan Permusyawaratan Desa dalam kutipan wawancara berikut:

"Ketika pembentukan BUMDes Tirta mandiri, Pemerintah Desa menyampaikan keinginannya lalu BPD menyelenggarakan musyawarah desa. Yang terlibat lebih jauh adalah pemerintah desa dan BPD. “

BUMDes Tirta Mandiri dibentuk dalam musyawarah desa yang diselenggarakan oleh BPD yang merupakan wakil masyarakat. Tujuan lain dalam pembentukan BUMDes adalah memberikan lapangan pekerjaan untuk masyarakat di Desa Ponggok. Setelah dibentuknya BUMDes Tirta Mandiri, dalam penentuan struktur juga melibatkan masyarakat dalam musyawarah desa.

Keterlibatan masyarakat dimulai dari perancangan, penyusunan hingga implementasi yang diselenggarakan oleh BPD yang merupakan wakil masyarakat Desa ponggok yang aktif di dalam musyawarah desa. Ketika BUMDes dibentuk masyarakat Desa ponggok ikut terlibat dalam BUMDes tersebut. Akses diberikan kepada masyarakat Desa Ponggok dalam memberikan masukan serta ikut serta dalam pengembangan BUMDes Tirta Mandiri. Peran masyarakat yaitu bekerja di unit usaha yang ada di BUMDes Tirta Mandiri. Kehadiran BUMDes Tirta Mandiri memberikan lapangan pekerjaan kepada masyarakat Desa Ponggok. Pada struktur BUMDes Tirta Mandiri masyarakat ikut berpartisipasi diwakili oleh BPD dalam menyelenggarakan musyawarah desa dalam pemilihan struktur BUMDes Tirta Mandiri dan dihadiri oleh masyarakat Desa Ponggok. Struktur BUMDes Tirta Mandiri dapat diawasi masyarakat dimana masyarakat berperan sebagai badan pengawas.

Partisipasi masyarakat Desa Ponggok terhadap proses BUMDes Tirta Mandiri dapat mengikuti dimulai dariperumusan hingga berjalannya BUMDes Tirta Mandiri, sehingga ketika pembentukan BUMDes Tirta Mandiri tidak hanya kepentingan elit politik dan elit masyarakat namun langsung kepada masyarakat dan meningkatkan perekonomian desa yang merupakan salah satu tujuan hadirnya BUMDes dalam memajukan perekonomian desa. Kehadiran
BUMDes memberikan pekerjaan bagi masyarakat desa untuk mengembangkan dan mengelola BUMDes Tirta Mandiri secara berdemokrasi dan bergotong royong.

Untuk lebih jelas pengelompokan aktor dalam BUMDes Tirta Mandiri dapat dilihat pada tabel di bawah ini:

Table 1 : Aktor dalam BUMDes Tirta Mandiri

\begin{tabular}{|c|c|c|c|c|}
\hline No & $\begin{array}{c}\text { Perumusan } \\
\text { dan } \\
\text { Pembentukan }\end{array}$ & $\begin{array}{c}\text { Tahun } 2010 \\
\text { sampai } \\
\text { Tahun } 2014\end{array}$ & $\begin{array}{c}\text { Tahun } 2015 \\
\text { sampai } \\
\text { tahun } 2019\end{array}$ & Tahun 2020 \\
\hline 1 & $\begin{array}{l}\text { Local state } \\
\text { (Pemerintah } \\
\text { Desa) }\end{array}$ & $\begin{array}{l}\text { Local state } \\
\text { (Pemerintah } \\
\text { Desa) }\end{array}$ & $\begin{array}{l}\text { Local state } \\
\text { (Pemerintah } \\
\text { Desa) }\end{array}$ & $\begin{array}{l}\text { Local state } \\
\text { (Pemerintah } \\
\text { Desa) }\end{array}$ \\
\hline 2 & Society (BPD) & $\begin{array}{l}\text { Society } \\
\text { (BPD) }\end{array}$ & $\begin{array}{l}\text { Society } \\
\text { (BPD) }\end{array}$ & $\begin{array}{l}\text { Society } \\
\text { (BPD) }\end{array}$ \\
\hline 3 & $\begin{array}{l}\text { Dunia Usaha } \\
\text { (Investor: } \\
\text { Individu } \\
\text { Masyarakat } \\
\text { Desa Ponggok) }\end{array}$ & $\begin{array}{l}\begin{array}{l}\text { Society } \\
\text { (masyarakat }\end{array} \\
\text { Desa } \\
\text { Ponggok } \\
\text { yang } \\
\text { menerima } \\
\text { manfaat } \\
\text { dan dampak } \\
\text { kehadiran } \\
\text { BUMDes } \\
\text { Tirta mandiri) }\end{array}$ & $\begin{array}{l}\begin{array}{l}\text { Society } \\
\text { (masyarakat }\end{array} \\
\text { Desa } \\
\text { Ponggok yang } \\
\text { menerima } \\
\text { manfaat } \\
\text { dan dampak } \\
\text { kehadiran } \\
\text { BUMDes } \\
\text { Tirta mandiri) }\end{array}$ & $\begin{array}{l}\begin{array}{l}\text { Society } \\
\text { (masyarakat }\end{array} \\
\text { Desa } \\
\text { Ponggok } \\
\text { yang } \\
\text { menerima } \\
\text { manfaat } \\
\text { dan dampak } \\
\text { kehadiran } \\
\text { BUMDes } \\
\text { Tirta } \\
\text { mandiri) }\end{array}$ \\
\hline 4 & & $\begin{array}{l}\text { Dunia Usaha } \\
\text { (Pengelola, } \\
\text { Investor: } \\
\text { Individu } \\
\text { Masyarakat } \\
\text { Desa } \\
\text { Ponggok) }\end{array}$ & $\begin{array}{l}\text { Dunia Usaha } \\
\text { (Pengelola, } \\
\text { Investor: } \\
\text { Individu } \\
\text { Masyarakat } \\
\text { Desa } \\
\text { Ponggok) }\end{array}$ & $\begin{array}{l}\text { Dunia Usaha } \\
\text { (Pengelola, } \\
\text { Investor: } \\
\text { Individu } \\
\text { Masyarakat } \\
\text { Desa } \\
\text { Ponggok) }\end{array}$ \\
\hline 5 & & & $\begin{array}{l}\text { Dunia } \\
\text { Usaha } \\
\text { Perbankan } \\
\text { BNI) }\end{array}$ & $\begin{array}{l}\text { Dunia } \\
\text { Usaha } \\
\text { (Perbankan } \\
\text { BNI) }\end{array}$ \\
\hline
\end{tabular}

Sumber: Data Primer yang diolah oleh peneliti Tahun 2020

\section{B. Sinergitas Aktor dalam Menjalankan BUMDes Tirta Mandiri}

Sinergitas menurut Deardorff dan Williams adalah sebuah proses dimana interaksi dari dua atau lebihagen ataukekuatan akan menghasilkanpengaruh gabungan yang lebih besar dibandingkan jumlah dari pengaruh mereka secara individual. Melalui sinergi, kerjasama dari paradigma yang berbeda akan mewujudkan hasil lebih besar dan efektif sehubungan proses yang dijalani menunjukkan tujuan yang sama. Bersinergi bertujuan memandukan bagian-bagian yang terpisah (Husaini, 2011).

Untuk mencapai tata kelola perusahaan yang baik (good corporate governance) dalam suatu kebijakan bukan hanya ketika perumusan kebijakan tersebut, tetapi sinergitas antar aktor dalam mengaplikasikan kebijakan. Mewujudkan sinergi bukan berarti berkompromi di tengah, melainkan membangun kerjasama-kerjasama kreatif dengan 
cara menghormati perbedaan, membangun kekuatan dan mengkompensasikan kelemahan. (Terry, 2019)

Peneliti memaparkan hasil temuan peneliti di lapangan melalui via daring dan turun lapangan secara langsung dan menganalisis sesuai teori sinergitas menurut Najiyati dan Rahmat dimana sinergi dapat diukur melalui komunikasi dan koordinasi. (Rahmawati,2014)

\section{a. Komunikasi antar aktor dalam BUMDes Tirta Mandiri}

Menghasilkan suatu hubungan yang sinergi maka komunikasi dan koordinasi yang baik harus terjadi dengan baik. komunikasi tidak dapat berdiri sendiri tanpa adanya koordinasi dalam berkomunikasi, begitu pula sebaliknya bahwa dalam dalam komunikasi dibutuhkan koordinasi yang jelas. komunikasi terjadi apabila sumber ingin menyampaikan informasi dan si penerima pesan memberikan tanggapan atas informasi yang disampaikan, sehingga adanya timbal balik dan terjalinnya komunikasi yang efektif. (Hasan, 2005)

Berdasarkan Anggaran Dasar dan Anggaran Rumah Tangga BUMDes Tirta Mandiri dalam hal laporan pertanggung jawaban struktur BUMDes Tirta Mandiri, pengelola BUMDes membuat laporan pertanggung jawaban lalu disetujui oleh badan pengawas. Laporan pertanggung jawaban yang telah disetujui di sahkan oleh kepala desa. Pengurus BUMDes menyelenggarakan laporan pertanggungjawaban dimana musyawarah desa di selenggarakan oleh BPD yang dilaksanakan maksimal setiap akhir bulan Maret tahun berikutnya. Ketika pengelola menyampaikan laporan pertanggungjawaban pengelola juga menyampaikan rencana kerja, dan rencana anggaran pendapatan dan biaya berikutnya yang sudah di sahkan.

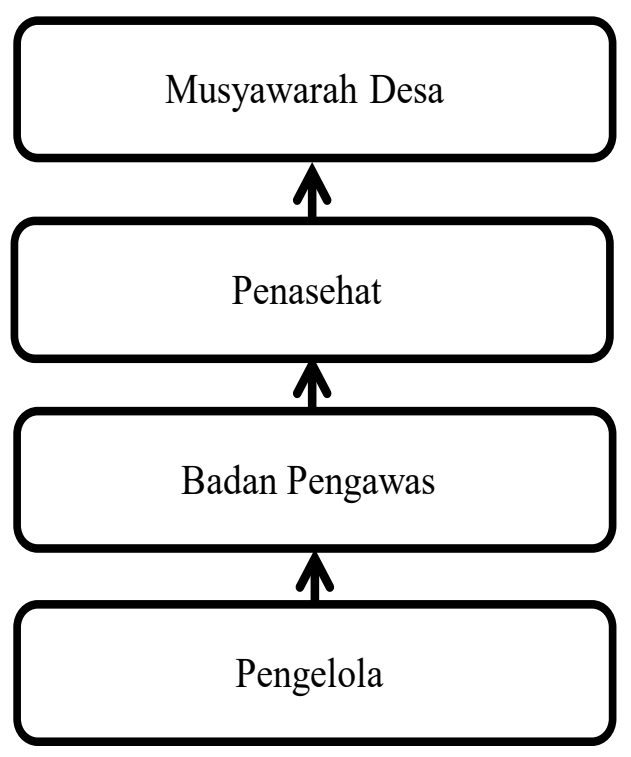

Sumber :Data Primer yang diolah oleh peneliti tahun 2020

Gambar 2. Alur Komunikasi BUMDes Tirta Mandiri

Peran dan Sinergitas Antar Aktor Badan Usaha Milik Desa (Bumdes) (Nastasya Aisya Putri, Aidinil Zetra, dan Roni Ekha Putera)
Alur komunikasi dimulai dari pengelola BUMDes Tirta Mandiri. Pengelola BUMDes Tirta Mandiri merupakan pemimpin dalam BUMDes Tirta Mandiri secara kelembagaan administrasi. Direktur yang merupakan pimpinan dalam mengelola BUMDes Tirta Mandiri memiliki kewajiban dalam pengelolaan BUMDes Tirta Mandiri yang melayani kebutuhan masyarakat Desa Ponggok dengan memanfaatkan potensi yang ada di Desa Ponggok.

Komunikasi selanjutnya Komunikasi vertikal ke atas yang merupakan setiap anggota organisasi selalu ingin didengar oleh para atasanya. (Sondang P. Siagian. 2014) Sehingga BUMDes Tirta Mandiri dalam memberikan laporan pertanggung jawaban sudah terlaksanakan oleh pengelola BUMDes Tirta Mandiri. Laporan pertanggungjawaban yang telah disetujui oleh Kepala Desa Ponggok lalu diselenggarakan musyawarah desa oleh BPD paling lambat akhir bulan Maret tahun berikutnya. Musyawarah desa yang diselenggarakan oleh BPD bukah hanya membahas laporan pertanggungjawaban namun juga menyampaikan rencana kerja, dan rencana anggaran pendapatan dan biaya berikutnya yang sudah di sahkan sebelumnya. Hal ini akan dibahas oleh pengelola BUMDes Tirta Mandiri bersama perangkat desa, BPD dan masyarakat yang ada. Komunikasi terjadi melalui musyawarah desa ini.

Dari analisis di atas dapat peneliti simpulkan bahwa dalam proses sinergi antar aktor dalam perspektif governance menurut Sondang P. Siagian sudah sepenuhnya dilaksanakan. Karena dapat dilihat bahwa laporan dan agenda rutin yang dilakukan oleh pengelola BUMDes Tirta Mandiri terlaksanakan dan melibatkan pihak masyarakat dan pemerintah serta komunikasi yang terjadi antar aktor yang ada di BUMDes Tirta Mandiri.

\section{b. Koordinasi antar aktor dalam BUMDes Tirta Mandiri}

Koordinasi menurut Silalahi merupakan integrasi dari kegiatan-kegiatan individual dan unitunit ke dalam satu usaha bersama yaitu bekerja kearah tujuan bersama.(Silalahi.2011) Mewujudkan koordinasi yang efektif dapat dilihat dari sembilan syaratmenurut Moekijat.(Triana,etc. 2014)

\section{Hubungan Langsung}

Koordinasi dapat lebih mudah dicapai melalui hubungan langsung diantara orang-orang yang bertanggung jawab. Melalui hubungan pribadi langsung, ide-ide, cita-cita, tujuan-tujuan, pandanganpandangan yang dapat dibicarakan dan salah paham, bila ada, dapat dijelaskan jauh lebih baik ketimbang melalui metode apapun.(Moekijat,1994)

Hubungan langsung antara pengelola BUMDes dengan penasehat memiliki hubungan yang baik. 
Hubungan baik ini tercipta langsung dari setiap koordinasi yang dijalin antara kepala desa dengan direktur BUMDes. Menurut Marry Parker Follet koordinasi mudah dicapai dengan hubungan langsung diantara orang-orang yang bertanggung jawab. (Moekijat,1944) Kepala Desa Ponggok, BPD, dan Direktur BUMDes Tirta mandiri memiliki hubungan koordinasi langsung yang lebih mudah dilaksanakan.

Hubungan langsung antara kepala desa dan direktur dilihat dari agenda rapat yang dilaksanakan sesuaidengankesepakatan.Hubunganiniberlangsung ketika penyerahan laporan pertanggugjawaban disetiap akhir bulan Maret tahun berikutnya dan ketika musyawarah desa dalam membahas unit usaha-usaha yang akan dikembangkan. Agendaagenda rutin yang telah ditetapkan di musyarawah desa.

\section{Kesempatan Awal}

Perencanaan dan kesepakatan awal merupakan awal mula tingkat koordinasi dalam suatu kebijakan. Dengan demikian tugas penyesuaian dan pernyataan dalam proses pelaksanaan menjadi lebih mudah. Kesempatan awal dalam BUMDes Tirta Mandiri dapat dilihat pada kutipan wawancara peneliti dengan Ketua BPD 2007-2019 sebagai berikut:

"Kesepakatan setelah melakukan sosialisasi di tingkat wilayah yang dimaksud wilayah di sini adalah BPD bersama pemerintah desa memberikan sosialisasi di tingkat wilayah $R W$. Di Desa Ponggok kan ada 6 wilayah RW, jadi kami istilahnya itu sosialisasi jemput bola mendatangi pertemuan bahkan menjabarkan sosialisasi tentang pembentukan badan usaha milik desa per $R W$ dari $R W 1$ sampai 6 karena itulah lembaga ini bisa menyimpulkan bahwa memang Badan Usaha yang didirikan sesuai dengan kebutuhan."

Dalam mendirian BUMDes Tirta Mandiri bahwa kesempatan awal menjadi salah satu faktor penting untuk mencapai koordinasi yang efektif. Dimana BUMDes Tirta Mandiri merupakan kesempatan awal agar perekonomian desa dapat meningkat. Ini disesuaikan oleh pendapat Tripathi dan Reddy dalam Moekijat yang mengatakan bahwa koordinasi dapat dicapai lebih mudah dalam tingkat-tingkat awal perencanaan dan pembuatan kebijaksaan (kesempatan awal).

\section{Kontinuitas}

Koordinasi yang dapat dilihat pada awalnya ketika pembentukan BUMDes Tirta Mandiri oleh PemerintahDesadandilanjutkan dengan musyawarah desa yang diselenggarakan oleh BPD. BUMDes Tirta Mandiri resmi dibentuk pada Desember 2009 dan setelah berdirinya BUMDes hubungan koordinasi antar aktor tetap berlanjut. Direktur BUMDes Tirta Mandiri menjadi pemimpin dalam melaksanakan pengelolaan BUMDes, badan pengawas mengawasi jalannya pengelolaan BUMDes, dewan penasehat selaku kepala desa memberikan saran, pendapat, nasehat kepada direktur BUMDes. Kegiatan ini selalu dilakukan setiap bulan dan akhir tahun

\section{Dinamisme}

Koordinasi yang baik harus secara terusmenerus diubah karena perubahan lingkungan baik intern maupun ekstern yang berarti koordinasi tidak harus terjadi secara kaku. Pada pengembangan BUMDes Tirta Mandirikoordinasi terjalin baik secara formal dan non formal. Dimana ketika pengelola BUMDes Tirta Mandiri selesai melaksanakan rapat rutin maka akan memberi perkembangan tentang inovasi-inovasi yang akan dibahas di musyawarah desa selanjutnya. Selain itu, dengan pihak ke-3 yaitu BNI diagendakan secara formal. Seperti yang disampaikan direktur BUMDes Tirta Mandiri ke-3 dalam kutipan wawancara berikut :

"komunikasi yang terjalin antara saya pimpinan BUMDes dengan kepala desa termasuk relatif simple dan tidak kaku, sebelum dibahas lebih lanjut dengan seluruh pihak, saya dan beliau berdiskusi ringan. Ini juga terjadi dengan pihak BNI namun tetap ada agenda formal"

Selain itu, dengan pihak ke-3 yaitu BNI kami juga membicara pembaharuan teknologi pembayaran melalui rapat bulanan. koordinasi yang terjalin antar aktor yang ada di BUMDes Tirta Mandiri dalam pengembangan bersifat formal dan lebih jelas, dengan koordinasi seperti ini akan membuat proses pencapaian koordinasi yang lebih efektif dan lebih mudah untuk dicapai.

\section{Tujuan Yang Jelas}

Dengan adanya tujuan yang jelas makan koordinasi yang diperoleh lebih efektif dalam organisasi. Aktor-aktor yang ada di BUMDes Tirta Mandirimengatahui dengan jelas tujuan dari dibentuk BUMDes tersebut. Tujuan BUMDes Tirta Mandiri ditulis dalam Anggaran Dasar dan Anggaran Rumah Tangga BUMDes Tirta Mandiri. Dimana tujuan dari dibentuknya BUMDes Tirta Mandiri adalah:

a. Peningkatan dan pengembangan kemampuan SDM sehingga mampu memberikan nilai tambah dalam pemanfaatan potensi dan pengelolaan aset ekonomi desa.

b. Mengintegrasikan produk-produk ekonomi pedesaan sehingga memiliki posisi nilai tawar baik dalam jaringan pasar.

c. Mewujudkan skala ekonomi kompetitif terhadap usaha ekonomi yang dikembangkan. 
d. Menguatkan kelembagaan ekonomi desa.

e. Mengembangkan unsur pendukung seperti perkreditan mikro, informasi pasar, dukungan teknologi dan manajemen, prasarana ekonomi dan jaringan komunikasi maupun dukungan pembinaan dan regulasi.

\section{Organisasi Yang Sederhana}

Struktur organisasi yang sederhana dapat memudahkan koordinasi yang lebih efektif. Struktur organisasi disesuaikan dengan kebutuhan yang ada disetiap organisasi. Dapat dilihat pada Bagan 1. Struktur pada BUMDes Tirta Mandiri memberikan dampak koordinasi yang jelas kepada masingmasing aktor dalam menjalankan BUMDes.

\section{Perumusan Wewenang dan Tanggungjawab Yang Jelas}

Wewenang dan tanggung jawab yang jelas merupakan faktor lain dalam memudahkan koordinasi. AD/ART BUMDes Tirta Mandiri mengatur dengan jelas setiap tugas dan fungsi aktor yang ada di BUMDes Tirta Mandiri. Wewenang dan tanggungjawab secara tegas dan jelas bagi setiap individu dapat memudahkan dalam tercapainya koordinasi yang efektif. Mengatur wewenang dan tanggungjawab agar aktor-aktor di BUMDes Tirta Mandiri dapat mengetahui dengan jelas tugas dan kewajiban serrta memudahkan tercapainya tujuan dari didirikannya BUMDes Tirta Mandiri.

\section{Komunikasi Yang Efektif}

Komunikasi yang efektif dilakukan dengan cara saling tukang informasi secara terus menerus, perbedaan-perbedaan individu, penyesuaian program, dan sebagainya yang dapat dibicarakan. Melalui komunikasi yang efektif setiap kegiatan dan tujuan dapat dibicarakan dengan baik secara seksama. Komunikasi antara Pengelola BUMDes Tirta Mandiri dan Kepala Desa Ponggok berjalan dengan lancar. Kepala Desa Ponggok dengan Direktur BUMDes Tirta Mandiri memiliki komunikasi yang lancar.

Komunikasi yang lancar dari masingmasing aktor memberikan dampat yang positif dalam menjalankan BUMDes, setiap agenda dan kegiatan serta yang berhubungan dengan BUMDes dikomunikasikan terus menerus baik secara formal maupun informal.

\section{Kepemimpinan dan Supervisi yang Efektif}

Kepemimpinan yang efektif dapat mengkoordinasi setiap kegiatan-kegiatan dari tingkat perencanaan maumpu pada tingkat pelaksanaan. Pemimpin merupakan salah satu intisari dalam hal manajemen, sumber daya, dan merupakan titik sentral dari setiap aktivitas yang terjadi dalam organisasi. Dinamika dan gaya kepemimpinan seorang pemimpin menentukan tujuan organisasi dapat dicapai atau tidak. Pemimpin yang demokratis, dinamis dan kreatif juga membuat komunikasi dan hubungan yang harmonis antar aktor yang ada di Desa Ponggok dapat bersinergi.

Kepemimpinan Direktur BUMDes Tirta Mandiri seperti yang disampaikan oleh Ketua BPD tahun 2007-2019 dalam kutipan wawancara dibawah ini:

"Mas Joko merupakan sosok pemimpin yang lebih fleksibel dan memiliki koordinasi yang baik antar lembaga yang ada, beliau sosokyang bertanggung jawab dan dapat bekerjasama. Contohnya ketika permasalahan surat-surat kemaren, padahal itu ada permasalahan di pemerintah desa. Namun ia ikut mengurusi bersama bapak kades. Cuma dia gak kepilih lagi kemaren."

Kepemimpinan yang efektif mampu mengkoordinasikan setiap kegiatan-kegiatan yang ada didalam organisasi. Menurut Ketua BPD tahun 2002-2019 bahwa Joko Winarno merupakan sosok pemimpin yang demokratis dan memiliki hubungan yang baik dengan aktor yang ada di BUMDes Tirta Mandiri.

Berdasarkan data-data yang peneliti temukan, koordinasi yang ada diantara aktor-aktor yang ada di BUMDes Tirta Mandiri sudah berjalan dengan baik. Pada strukturunit usaha terdapat empat unit usaha dan di BUMDes Tirta Mandiri dapat bertambah sesuai dengan perkembangan BUMDes. Keempat unit sudah berkembang dengan baik dan membuktikan bahwa koordinasi antar aktor yang ada di BUMDes Tirta Mandiri yang dilihat dari sembilan syarat untuk mencapai koordinasi yang efektif menurut Najiyati dan Rahmat.

Dari data-data yang telah peneliti temukan dan telah peneliti jelaskan diatas, proses sinergitas yang terjadi antar aktor di BUMDes Tirta Mandiri peneliti digambarkan pada Gambar 10.

Sinergitas antar aktor dalam mengembangkan BUMDes Tirta Mandiri yang dilihat dari teori sinergitas menurut Najiyati dan Rahmat dimana sinergi dapat diukur melalui komunikasi dan koordinasi. Pada bagan 4 dapat dilihat bahwa dalam mengembangkan BUMDes Tirta Mandiri, pengelola BUMDes selalu berkomunikasi dan berkoordinasi dengan pihak pemerintah desa dan masyarakat desa. Pemerintah desa merupakan penasehat dalam struktur BUMDes Tirta Mandiri. Masyarakat memiliki peran dalam mengembangkan BUMDes Tirta Mandiri sebagai badan pengawas yang diwakilkan oleh BPD. Selain pemerintah desa dan masyarakat, ada pelaku usaha yang ikut dalam mengembangkan BUMDes 
Tirta Mandiri yaitu pengelola dan pihak ketiga. dalam pengembangan BUMDes Tirta Mandiri, pengelola BUMDes akan melaporkan pada akhir tahun di musyawarah desa yang diselenggarakan oleh BPD. Hal ini bertujuan agar seluruh masyarakat Desa Ponggok ikut terlibat dalam mengembangkan BUMDes Tirta Mandiri.

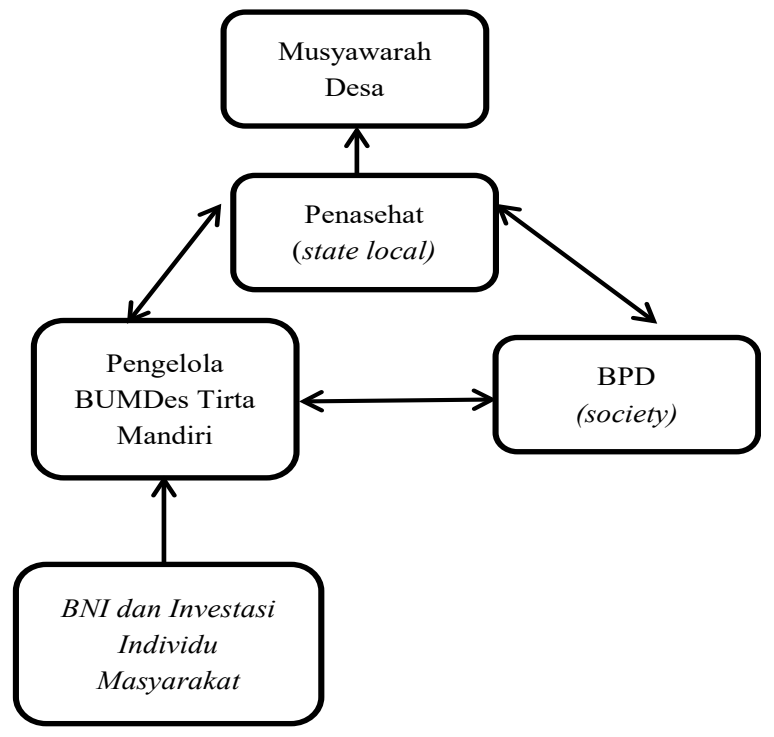

Sumber: Data Primer yang diolah oleh peneliti tahun 2020

Gambar 3. Sinergitas antar aktor dalam mengembangkan BUMDes Tirta Mandiri

\section{SIMPULAN}

Berdasarkan temuan dan analisis peneliti, maka peneliti memiliki kesimpulan yang sesuai dengan pertanyaan penelitian bahwa aktor yang terlibat dalam pembentukan BUMDes Tirta Mandiri adalah state local dan society. State local memiliki peran dalam perumusan, pembentukan dan menjadi pengawas dalam menjalakan BUMDes Tirta Mandiri, sedangkan society yang diwakilkan oleh BPD menyelenggarakan musyawarah desa ketika pembentukan dan evaluasi serta pemilihan pimpinan BUMDes Tirta Mandiri. Society juga mendapatkan lapangan pekerjaan dan kehadiran BUMDes.

Kedua aktor tersebut memiliki peranan yang sangat menentu baik dalam merumuskan, menetapkan dan mengimplementasikan kebijakan. Kedua aktor memiliki kesejajaran dan porsi yang sama serta berkesempatan untuk terlibat dalam pengambilan keputusan. Selain itu, adanya akademisi dalam membantu pemerintah desa untuk meyakinkan masyarakat desa bahwa pembentukan BUMDes Tirta Mandiri bertujuan untuk memajukan perekonomian desa dan mengelola sumber daya yang ada. Civil society juga diperankan oleh masyarakat ketika pembentukan BUMDes Tirta Mandiri yang menjadikan masyarakat sebagai investor dalam tahap pembentukan BUMDes Tirta Mandiri.
Sedangkan dalam menjalankan BUMDes Tirta Mandiri aktor-aktor juga memiliki sinergitas dalam menjalankankannya. Sinergitas yang dimaksud dengan tercapainya indikator-indikator menurut Najiyati dan Rahmat dapat diukurmelaluikomunikasi dan koordinasi. Hubungan antar aktor pada penelitian ini terhadap aktor-aktor lainnya saling berhubungan terutama masyarakat sebagai pengguna sekaligus sebagai pengawas dan pemilik modal.

\section{DAFTAR PUSTAKA}

Anggaran Dasar dan Anggaran Rumah Tangga BUMDes Tirta Mandiri Tahun 2018

Dodi Faedlulloh. 2018. BUMDes dan Kepemilikan Warga: Membangun Skema Organisasi Partisipatoris. Journal of Governance. 3,(1).

Firdaus, Syahran. 2017. "Fenomena Elite Capture dalam Pengelolaan Badan Usaha Milik Desa (BUMDes): Studi kasus strategi bekerjanya kekuasaan elite dalam pengelolaan BUMDes Argosari, Desa Pulosari, Kabupaten Pemalang". Universitas Gadjah Mada.

Furniss, N. 1974. The Practical Significance of Decentralization. The Journal of Politics. 29, (4), 961

Gusnadi, Pratiwi Budiharta. 2008. Analisis Pengaruh Karakteristik Perusahaan dan Penerapan Good Corporate Governance Terhadap Tindakan Perataan Laba yang Dilakukan oleh Perusahaan yang Terdaftar di Bursa Efek Jakarta. Jurnal Modus. 20,(2), 126-138

Hasan Erliana. 2005. Komunikasi Pemerintahan. Bandung: Mandar Maju.

Himawan, Prambudi. 2001. Politik Pemberdayaan: Jalan Mewujudkan Otonomi Desa. Yogyakarta: Lapperapustala Utama.

Husaini Usman. 2011. Manajemen Teori, Praktek Dan Riset Pendidikan Jilid 4. Jakarta: Bumi Aksara.

Ibrahmi, dkk. 2020. Dari Ekonomi Ke Ekonomi Politik: Transformasi Setengah Hati Sektor Ekowisata Di Bangka Belitung. Jurnal Wacana Politik. 5,(2), 174 - 184

Keputusan Kepala Desa Ponggok Kecamatan Polanharjo Kabupaten Klaten Nomor: 141/11/XII/2009 Tentang Penyerahan AsetAset Usaha Desa Ke BUMDes Tirta Mandiri tahun 2020

Mardiasmo. 2009. Akuntansi Sektor Publik. Yogyakarta: Andi Yogyakarta 
Mahpudin dan Yugni Maulana Aziz. 2021. Rent Seeking Dan Praktik Korupsi Di Tubuh Bumd: Kasus Bumd PT Banten Global Development (BGD). Jurnal Wacana Politik. 6,(1), 37-48.

Moekijat. 1994. Koordinasi (suatu tinjauan teoritis). Bandung : Mandar Maju

Pratama, Sandy. 2018. Dimensi Ekonomi Politik Dalam Konflik Tata Kelola Pertambangan (Studi Kasus Surat Keputusan Gubernur Bangka Belitung Tentang Penghentian Sementara Operasional Pertambangan Laut PT Timah, Tbk Tahun 2016). Jurnal Wacana Politik. 3,(1), $40-53$.

Peraturan Daerah Klaten Nomor 2 Tahun 2009

Peraturan Desa Ponggok Nomor 6 Tahun 2009

Peraturan Menteri Desa, Pembangunan, Daerah Tertinggal, dan Transmigrasi Nomor 4 tahun 2015 tentang Badan Usaha Milik Desa

Rahmawati, Triana etal.2014. Sinergitas Stakeholders dalam Inovasi Daerah (Studi pada Program Seminggu di Kota Probolinggo (SEMIPRO)). Malang: Universitas Brawijaya.

Salganik, M. J.. Douglas D. H. 2007. Sampling and Estimation in Hidden Populations Using Respondent - Driven Sampling. Journal Sociological Methodologi Vol 34 No 1.
Sedarmayanti. 2004. Good Governance (Pemerintah Yang Baik) Bagian Kedua. Bandung: CV. Mandar Maju.

Suharko. 2005. Masyarakat Sipil, Modal Sosial dan Tata Pemerintahan yang Demokratis. Jurnal Ilmu Sosial dan Ilmu Politik. Vol 8 No 3. 263290

Terry Tresna Purnama. 2019. Implementasi Sinergitas dan Kemitraan Insan Litbang Akmil dalam Mewujudkan The World Class Military Academy. Tesis. STIE Widya Wiwaha.

Triana, Rahmawati, etc. 2014. Sinergitas Stakeholders dalam Inovasi Daerah. Jurnal Administrasi Publik (JAP). 2 (4). 641-647

Ulber Silalahi. 2011. Asas-asas manjemen. Bandung: Refika Aditama.

Widiastuti, Harjanti. 2019. Menakar tata kelola Badan Usaha Milik Desa di Indonesia. Jurnal Ekonomi dan Bisnis. 22, (2), 258-288.

Zulkarnaen, Reza (2016). Pengembangan Potensi Ekonomi Desa Melalui Badan Usaha Milik Desa (BUMDes) Pondok Salam Kabupaten Purwakarta. Jurnal Dharmakarya. 5,(1) 